\title{
Siyasalın Gündelik Kuruluşu Bağlamında Sokak Siyaseti ${ }^{1}$
}

\author{
Funda ÇOBAN \\ İzmir Demokrasi Üniversitesi, İ̈BF, Uluslararası İlişkiler \\ funda.coban@idu.edu.tr, ORCID: 0000-0001-5852-9386
}

\begin{abstract}
Öz
$\mathrm{Bu}$ çalışma, siyasalın gündelik kuruluşu bağlamında sokak siyaseti adı verilen teorik çerçeve üzerine bina edilmiştir. Buna göre çalışma önce siyaset ve siyasal kavramları arasında bir ayrışmaya gitmektedir. Daha sonra siyasalın tanımlanmasına paralel, siyasalı bir alan mücadelesi olarak resmetmektedir. Bu çerçevede de alan kavramının içinde yer alan uzam ve zaman yüklemlerini makro yapılar açısından nesnel uzam-zaman, mikro yapıdaki aktörler öznel uzamzaman boyutlarıyla ele almaktadır. Buna istinaden de mikro aktörlerin bakış açısından sokak siyasetini aktörler, örgütlenme biçimi, eylem alanları, eylem repertuvarları bakımından açıklamaktadır. En nihayetinde çalışma, açıklanan bu çerçevenin teorik sınırlarını daha iyi belirginleştirmek adına siyasalın gündelik kuruluşu bağlamında sokak siyasetini Bayatçı anlamda sokak siyaseti ile karşılaştırarak okumakta ve aralarındaki ilişkileri serimlemektedir.
\end{abstract}

Anahtar Kelimeler: Toplumsal hareketler, sokak siyaseti, direniş pratikleri, gündelik hayat, toplumsal mobilizasyon

JEL Sınıflandırma Kodları: Y8, Y80, Z10,

\section{Street Politics in the Context of Everday Construction of Political ${ }^{2}$}

\begin{abstract}
The study at hand focuses on the theoretical framework named street politics in the context of everyday construction of political. According to that, the article firstly makes a general distinction between the concepts, politics, and political. Following this, it depicts political as a struggle for a field. By addressing the field including the two dimensional concepts time, and space it makes another distinction between objective time-space settings and the subjective time-space compositions which all correspond to the confrontation between the macro-level structures and micro-level agents. Thus, the study explains street politics (in the context of everyday construction of political) in terms of actors, organizational form, action areas, and action repertoires. In the end, it compares street politics in the context of everyday construction of political with street politics by Bayat. Thus, it clarifies the conceptual and theoretical framework in a comparative way.
\end{abstract}

Keywords: Street politics, resistance praxises, everyday life, social mobilization JEL Classification Codes: Y8, Y80, Z10

\footnotetext{
${ }^{1}$ Makale, 2013 yılında Ankara Üniversitesi Sosyal Bilimler Enstitüsü Siyaset bilimi Anabilim Dalı'nda yazılan Siyasalın Gündelik Kuruluşu Bağlamında Sokak Siyaseti başlıklı doktora tezinin bir kısmından türetilmiştir. Tezin Metis Yayınevi'nden çıkan 2015 basımlı kitabından da kısmen yararlanılmıştır. Yayınevinden, ilgili izinler alınmıştır.

${ }_{2}^{2}$ Extended abstract is presented at the end of the article.
} 


\section{Giriş}

İnsanlık tarihi çeşitli hakikat söylemleri eliyle sürdürülen yönetim mantıklarının (yönetimselliklerin) yürüttüğü yapma etmelerin tarihinden ibaret olduğu kadar, bu yapma etmelere yönelik tepkilerin, direnişlerin ve saldırıların tarihinden de oluşur. $\mathrm{Bu}$ karşılıklı mücadele diyalektiği, çok çeşitli eylem biçimlerini, hedefleri ve sonuçları doğurmaktadır.

İşte bu makale, siyasalın gündelik kuruluşu bağlamında sokak siyaseti adı verilen ve bahsi geçen mücadele diyalektiklerini anlamak üzere çizilen teorik çerçevenin genel hatlarını açıklamakta, bu hatlardan türeyen temel kavram ve yaklaşımları Bayat'a (2009) ait sokak siyaseti çerçevesi ile -benzer bir arka plana sahip oldukları için- karşılaştırmaktadır. Bu perspektiften çalışma iki ana bölüme ayrılmıştır. Birinci bölümde siyasalın gündelik kuruluşu bağlamında sokak siyasetinin temel özellikleri anlatılmaktadır. İkinci bölümde ise, bu çerçevenin Bayat'ın bahsedilen teorisi ile ilişkisi ele alınmaktadır.

\section{Siyasalın Gündelik Kuruluşu Bağlamında Sokak Siyaseti}

Siyasal, toplumsal arenanın unsurlarından yapı (kültür, sınıf, devlet, hukuk, ekonomi gibi) ile bu yapılar içinde hareket eden faillerin/aktörlerin karşılaşma ve savaşımlarıyla her gün yeniden üretilen/inşa edilen agonistik bir alan (field) mücadelesidir (Mouffe, 2010, s.28). Bu anlamiyla siyasal, parti, parlamento, hükümet gibi modern siyasal iktidar aygıtlarının insanları idare etme, sınıflama, düzenleme ve disipline etme etkinliklerinin uzmanlaşmış alanını gösteren modern anlamlı siyaset olgusundan farklı olarak toplumsal alanda aktör ve yapıların karş111klı etkileşimiyle ortaya çıkan bir politik anlamlar demetine işaret eder. Söz konusu anlamlar demetiyse, alan kavramına içkin olan iki temel yüklemin, zamanın ve mekânın farklı kombinasyonlarla, mücadele içindeki taraflarca kullanılması ve üretilmesi vasıtasıyla gerçekleşir. Burada zaman yüklemi, yapının unsurları tarafından düzenlenmiş ve geçmiş-şimdi-gelecek kiplerinden oluşan ardışıklıkla tanımlı nesnel zaman haricinde, bu nesnel zamanı eğip bükerek, kendi çıkarlarına ve arzularına göre kullanmayı öngören öznel zaman boyutuna sahiptir. Benzer bir mantıkla uzam da nesnel ve öznel olmak üzere iki boyuta sahiptir.

$\mathrm{Bu}$ terimlerle yeniden düşünüldüğünde siyasal da zamanın ve uzamın sınırlarının çizilmesi, değiştirilmesi ve zaman zaman da muğlaklaştırılması olarak yeniden tanımlanabilir (Çoban, 2015). Nitekim hem yapının aktörleri hem de eylemin failleri/aktörleri, kendi zaman ve uzam düzenlemeleri uyarınca zaman zaman karşılaşır, politik anlamlar üretirler.

Sokak siyaseti, siyasal mücadelenin bu karş1lıklı mücadelesinden doğar ve burada sokak kavramı bilhassa önemlidir. Zira yapının öte yanında eylemin taşıyıcısı aktörler açısından bağlamı inşa eden temel yapıdır. Nitekim niceliksel olarak sokakların, siyasalın şekillendiği ana yerler olan kamusal açık alanların yüzde 
80'ini kapladığı tahmin edilmektedir (Wooley, 2003, s.107). Niteliksel olarak ise bunlar, siyasal kriz potansiyeli yüksek kamusal bir uzamı imlemektedir. Bu çerçevede sokak, bir yandan "aktörlerin, sayesinde ortak çıkarlarını konuştukları, kolektif düşüncelerini paylaştıkları ve bu nedenle tanımadıkları insanlarla dayanışmayı biçimlendirdikleri" (Bayat, 2009, s.16) somut bir mekân, bir yandan da "muhalefetlerini dile getirecekleri kurumsal bağlamdan yapısal olarak yoksun olanların toplu halde kendilerini ifade etmelerinin tek alanı" (Bayat, 2009, s.45) olarak kentsel ilişki ağıdır. Diğer bir ifadeyle sokak yalnızca insanları somut olarak bir araya getiren bir mekân düzenlemesi değil, aynı zamanda insanlar arasında ortak kimlikler yaratan soyut bir zaman düzenlemesidir. Kentsel biçimin tüm zamanları buradalaştırarak, herkesi aynı şimdide yaşatması tasarısına (Lefebvre, 2007, s.196) karşı, parçalı zamanlar üreten ve bu parçaları yeniden kurgulayan bir şebekedir. $\mathrm{Bu}$ anlamıyla sokak, "öznenin kentsel çarkın zorlamalarını bozarak onu yeniden üretmesi, kentin dış düzenine kendi uzam tüketicisi yasasını zorla kabul ettirmesi neticesinde," (Certeau, 2009, s.37) farklı türden insan etkinliklerini ve değişik karşılaşmaları besleyerek siyasal anlamlı mücadelelere sahne olan bir alan (field) haline gelir.

Bununla birlikte bir zaman ve mekân düzenlemesi olarak sokakta ya da sokak kapsamında cereyan eden her olay, siyasal nitelik taşımaz ya da bunların en azından siyasal anlamdaki değeri görecelidir. Örneğin geçimini sağlamak için işportacılık yapan birinin eyleminin etkinliğinin siyasallığı ile ülkedeki istihdam politikalarını protesto etmek için bir araya gelen işportacıların etkinliğinin siyasal niteliği arasında fark vardır. Ancak her iki etkinliğin de burada kullanılan anlamıyla siyasal bir edim gerçekleştirdiği teslim edilmelidir. Zira ilk örnekteki işportacı, yaptığı sessiz tecavüzle ekonomik bir alan tutmaktadır. İkinci örnekteki işportacıların protestoları ise doğrudan ifade edilen siyasal talepler içerir. Şu halde sokak etkinliklerinin birçoğu siyasal olarak tanımlanabilir; ama hepsi aynı derecede egemen iktidar ilişkilerinin yapısına meydan okumaz ya da bu yapıyı değiştirmeye kalkmaz. Sokak etkinliklerinin siyasal anlama meydan okumasının düzeyi, etkinliklerin meydan okuduğu egemen iktidar ilişkilerinin ve bunlara ait sembollerin büyüklüğü ile ölçülebilir. Diğer bir ifadeyle sokaktaki aktörün kendi toplumsal tecrübe ufkuna ve uzamsal deneyimine zit düzenlemelerin ve tahakküm mekanizmalarının çapı büyüdükçe, bu aktörün eyleminin siyasal niteliği artacaktır. Örneğin patriarkal iktidar ilişkilerinin hüküm sürdüğü her toplumda, kadının sokaktaki "marjinal davranışları," aslında siyasal anlamı yüksek bir eylemlilik biçimini ifade etmektedir. Burada karşılaşmanın tepe noktasında, aktörler arasında alan tutma mücadelesi kızışmaktadır. Aynı örnekten devam edildiğinde, söz konusu nesnel uzamın erkek egemen değerleri kollayacak şekilde örgütlendiği varsayılırsa, kadın o uzamdan dışlanacak, buna karşı direnirse de açık uçlu bir alan mücadelesi başlayacaktır.

İşte bu noktada sokağın bu siyasal potansiyeli, onu daima gündelik hayatın konusu haline getirmektedir. Çünkü sokak, içinde barındırdığı uyum ve çatışma 
potansiyellerini, "bizleri içeriden sıkı sıkıya yöneten" (Certeau, 2009, s.26) gündelik hayatın akışından devşirmektedir. Gündelik hayatın içindeki bu akış, Lefebvre'nin iddia ettiği gibi yalnızca modern hayata eşlik eden rasyonalite, planlama, tüketim unsurlarıyla değil (Lefebvre, 2007, s.41,50, 86), kendi içinde bir yaratıcılığı, üreticiliği ve beklenmeyeni de kapsayan yaşam pratikleri ile karakterize olmaktadır. $\mathrm{Bu}$ nedenle gündelik hayat dinamikleri içinde değerlendirilebilecek pek çok eylem siyasal alanın şekillenmesinin kurucu birer unsuru olarak düşünülebilir. Dolayısıyla gündelik hayatın taşıdığı akışkanlık ve değişkenlik siyasal alanı her gün yeniden kurar. Planlamacıların panoptik bakışına karş1 kullanıcıların oligopoktik vizyonu bunun temel direğidir (Healy, 2006). Nitekim Foucaultcu anlamdaki panaptikona karşıt bir kavram olarak Latour'un kavramı oligoptikon, kullanıcıların küreseli yerelleştirmesini, bir bütünlük olarak sunulan şehrin az bir kısmını; ama çok iyi bir şekilde görmesini ifade eder. Oligoptik bakışa göre örneğin Paris diye bir şehir yoktur. Sadece bir kısım tasarımcıların üretmeye çalıştığı bütünsel bir Paris vardır. Kullanıcıların zihninde ise şehrin nesnelliği hayal gücü/yaratım (imagination) tarafından çözündürülür. $\mathrm{Bu}$ cepheden, uzamın ve zamanın sınırları, makro düzey aktörler tarafindan olduğu kadar mikro düzey aktörler tarafından da her gün yeni baştan çizilir ve değiştirilir. Dolayısıyla basit hak savunularından devrime her türlü siyasal mücadele sürekli ve gündeliktir. (Vollrath, 1973, s.83). Tarih, yalnızca sinıf savaşı değil, alan savaşıdır $d a$ (Bourdieau, 1989, ss.14-25)

$\mathrm{Bu}$ itibarla siyasalın gündelik kuruluşu bağlamında sokak siyaseti belli bir coğrafyaya veya zamana özgülenemez. Evrensel olarak, tahakküm ve direnişin olduğu her mekân ve zamanda bulunur. Öte yandan karşılaşmaların daha yoğun yaşandığı mekânlar olarak şehirler, siyasalın gündelik kuruluşu bağlamında sokak siyasetinin ana arterini teşkil eder. Dolayısıyla buradaki evrensellik ve alan genişliği eylemlere yön veren aktörlerin sayısını hayli artırır.

Ortak bir kategori altında söylendiğinde sokak siyasetinin aktörleri, siyasal alan mücadelesinde egemen iktidar ilişkilerinin dikkate almadığı, sessizleştirdiği, görmezden geldiği ya da kriminalize ettiği kişi ve gruplardır. Söz konusu grupların tanımı ise, tarihsel süreçteki iktidar ilişkilerinin politik, ideolojik ve ekonomik kompozisyonuna göre değişmektedir. Bu minvalde, aktörler egemen siyasal iktidarın mantığı uyarınca değişik biçimlerde zamanın egemen söylemine göre kategorize edilir ve/veya kriminalize edilirler. Örneğin yaklaşık 1540'a kadar en geniş şekilde ele alınan günah, açık arayla cimriliktir (Ginzburg, 2007, s.188). 1628 'de Strazburg polis yönetmeliğinde polisin yetki alanına giren konulardan biri oburluktur (Neocleaus, 2006, s.6). Benzer bir mantıkla 15. ve 16. yüzy1llarda cadılar, 17. yüzyıl İngiltere'sinde Serserilik Yasası'nın kriminalize ettiği rastgele ve örgütlü suçlular (kapkaççılar, fahişeler, haraç alanlar, aylaklar) ile "cinsel ahlaksızlık" (zina ve sodomi) yapanlar (Reynolds, 2002, s.15) 1748'de Avusturya verasetinin bitmesinin ardından gazete haberlerinde potansiyel suçlu olarak mimlenen askerler ve denizciler (Rawlings, 2002, s.125), yoldan çıkmışlığın 
gösterge birimi egzantrikler (Gill, 2009, ss.20-27), günümüzde göçmenler, evsizler, deliler, mülteciler, dilenciler ve anarşistler aynı söylemsel düzenin farklı coğrafyalarda ve dönemlerde ortaya çıkardığı özneleş̧tirme biçimlerine konu olan aktörlerdir. Bu açıdan genel bir ifadeyle sokak siyasetinin aktörleri ekonomik, yasal ya da kültürel olarak kamusal alanda temsil ve ifade özgürlüğünden mahrum bırakılmış olanlar ile bu özgürlükleri kurumsallaşmış siyasal mekanizmalara alternatif siyasal araçlarla derinleștirmek niyetinde olanlar olarak tespit edilebilir. Politik bir bilinçle hareket eden bu ikinci grup aktörler paranteze alınırsa, buradaki mahrumiyet tarihsel bir sürecin sonucundan kaynaklanabileceği gibi (örneğin kadınlar), egemen siyasal iktidarın aniden çıkaracağı yasal bir düzenleme neticesinde de belirebilir (Örneğin 1940'larda Türkiye'de Varlık Vergisi Yasası nedeniyle madunlaşan kent soylu eski azınlıklar). Üretim biçiminin koşullandırdığ 1 üretim ilişkilerinin bir görüngüsü olarak meydana gelebileceği gibi (örneğin köleler), egemen iktidar ilişkilerinin söylemindeki bir değişiklikten de (örneğin 17. yüzyıla dek akşamcı nightwalker sözcüğünün ahlakla ilgili hiçbir çağrışımının bulunmamasına karşılık, bu dönemden sonra kelimenin sokaktaki iffetsiz kadınları işaret etmek üzere kullanılması (Griffiths, 1998) kaynaklanabilir. Neticede içinde sokağı örgütlemeye yönelmiş ve doğrudan eylem bilinci taşıyan kişiler barındırmakla birlikte siyasalın gündelik kuruluşu bağlamında sokak siyasetinin aktörleri hemen herkes olabilir.

Siyasalın gündelik kuruluşu bağlamında sokak siyasetinin örgütlenme ayağında ise söz konusu sıradan insanlar arasındaki iletişimi kuran bir ilişki şebekesi olarak sokak dolayımıyla kurulan pasif ağlar yer alır. Pasif ağ ise, "atomize bireyler arasındaki ortak kimliklerin sessizce tanınmasıyla ve mekân aracılığıyla kurulan ani iletişim vasıtasıyla yürütülen" gevşek yapılı bir örgütlenme biçimine denk gelir (Bayat, 2009). Örneğin bir toplu taşım aracında araçtaki yolcuların vicdanına seslenen bir durum vuku bulduğunda -örneğin parası olmayan bir yolcunun araca alınmaması- yolcuların kendiliğinden olarak şoföre tepki vermesi mikro bir pasif ağ örneğidir. Bu pasif ağların alanında, güdümlü ve planlı bir şekilde ilerletilen stratejilere karşılık bir merkezden yoksun olan taktik (metis) (Certeau, 1990, s.54) hüküm sürer. Böylelikle sokak siyaseti kaba kuvveti olabildiğince inceltir. Taktiklerin çok biçimli zaman-uzamında eylem alanlarını sınırsızlaştırır. Her yeri bir operasyon zemini kılar.

Pasif ağların her yeri bir anda operasyon zemini kılma yeteneği, siyasalın gündelik kuruluşu bağlamında sokak siyasetinin spontaneliğini ve doğrudanlığını açığa çıkarır. Kurumsal olarak örgütlenme düzeyi yüksek olmadığı için sorunun çözümüne ya da siyasal anlamın değiştirilmesine yönelik spontane ve doğrudan çözümlerin üretilmesi, gündelik hayatın eyleme ve sonuca odaklı karakterinden türer. Paralel şekilde, bu doğrudanlık ve spontanelik onu hiyerarşisiz, bürokrasiden azade ve âdem-i merkeziyetçi kılar. Aynı örnekten devam edersek, parası olmayan yolcunun araca alınması için yolcuların şoföre verebileceği tepkiler ya da birilerinin çıkıp parasız yolcunun ücretini ödemesi pasif bir a $\breve{g}$ 
kuran bir topluluğun doğrudanlığını, spontaneliğini ve hiyerarşisizliğini örnekler. Zira burada yapılan eylem, parası olmayan yolcunun araca alınması yönündeki talebe bir karşılık bulurken doğrudan, bir örgütlenme ağı barındırmaması, dolayısıyla planlanmamış olmasıyla spontane, ağ içindeki kişilerin statüleri ile ilgisiz olması nedeniyle hiyerarşisiz, aktörlerin bireysel kararlarına dayandığı için de özyönetimcidir.

$\mathrm{Bu}$ noktada siyasetin gündelik bağlamında sokak siyasetinde siyasal bilincin tuttuğu yeri belirlemek önemlidir. Başka bir ifadeyle, sokak siyasetini şekillendirenler hiçbir siyasal hedefi olmayan ya da hedeflerini politik bir dile tercüme edemeyenler midir? Böylesi bir ölçüt, kurumsal siyasetin dışında şekillenen; ancak kamusal alanın kullanımını, zaptını ya da ajitasyonunu hedef almakla birlikte toplumsal hareket olma düzeyine ulaşmamış pek çok siyasal mücadele ve pratiği örgütlemeye çalıştığı sokağın alanının dışına koymaktadır. Bundan farklı olarak siyasalın gündelik kuruluşu bağlamında sokak siyasetinin aktörleri ise eylemlerine dönük siyasi bir bilinç ve amaç taşıyor ya da taşımıyor olabilirler. Çünkü egemen siyasal iktidara hâkim olmayı hedef almayan ya da onu yıpratmaya çalışmayan pratiklerin kendi içinde gizil bir bilinç barındırdığı varsayllabilir. Çünkü belli bir alana yönelik herhangi bir pratik, "bir şeylerin başka türlü olması gerektiği" varsayımını içinde barındırır. "Bir şeylerin başka türlü olması gerektiğini" düşünmek ise, mevcut iktidar ilişkilerinin kurduğu ekonomik, politik ve ideolojik yapılara yöneltilen- dillendirilmiş olmuş ya da olmasın - bir itirazdır. Zira eylemek, direkt olarak zamana ve uzama bir müdahalede bulunmaktır.

Şu hâlde siyasalın gündelik kuruluşu bağlamında sokak siyasetini mümkün kılan, onu koşullayan ve sonuca ulaştıran ana unsuru bulmak gerekir. Sorunun yanıtı, siyasalın gündelik kuruluşu bağlamında sokak siyasetinin öznel zaman ve uzam düzenlemelerine politik anlam veren araçlar ve taktiklerinde gizlidir. Zira bir alan mücadelesi olarak siyasalın mikro boyutunda failler, nesnel zaman ve uzam düzenlemelerine karşı kendi özerk alanlarını korumada ve yaratmada bu araçları ve taktikleri kullanırlar. Burada araçlar, öznel zaman ve uzam manipülasyonlarının zihinsel haritasını, taktikler bu zihinsel haritanın edimselleşmiş biçimini ifade ederler. Örneğin aylaklık, çalışmayı kutsayan Protestan etiğinin nesnel zaman düzenlemesine karşı, öznel zaman düzenlemesini mümkün kılan bir varoluş biçimi olarak bir araç, çalışmamak için bahaneler uydurma da bir taktiktir. Genel hatları itibariyle öznel zaman ve uzam düzenlemeleri yapabilme kapasitelerini fiiliyata döken ideal tipteki sokak siyaseti araçları karnavallaşma, mizah, müzik/dans, fantasma (hayal), esriklik, aylaklık, oyun, armağan, sokak sanatları, internet, spontane toplanmalar ve işgallerdir. $\mathrm{Bu}$ araçlar sokak siyasetinin amaçlarını, aktörlerini ve örgütlenme biçimlerini sınıflandırmak için de asal bir zemin teşkil etmektedir. Bu zemin üzerinde, mikro düzey failler üç nitelikte senaryo üretmektedirler: 


\subsection{Savunmaci Nitelikteki Senaryolar}

İçeriklerini teşkil eden araçların ve taktiklerin sıradanlı̆̆ $\breve{l}$ nedeniyle, gündelik yaşamın olağan akışı içinde üretilirler. $\mathrm{Bu}$ bağlamda da siyasalın gündelik kuruluşu bağlamında sokak siyaseti repertuvarının en büyük parçasını teşkil ederler. Bunlar hayatın rutin akışı içine öylesine nüfuz etmişlerdir ki, gündeliğin siyasal anlam üreten niteliğinden azade görünürler. Gülme, aylaklık, karnaval, armağan, fantasma, müzik ve dans, oyun, esriklik bu kategoriden sayllabilecek kimi araçlar, yalan, dedikodu, iş yaşamında kaçamaklar (bilmezlikten gelme, işten çalma, ayak sürüme) bu kategoride sayılabilecek kimi taktiklerdir. Öte yandan, içinde koşullandıkları toplumun ekonomik, politik ve ideolojik arka planının, bu pratiklerin niceliğini ve niteliğini değiştireceğini şerh düşmek gerekir. Örneğin, aylaklık ancak Protestan etiğinin bir görünümü olarak çalışmanın kutsandığ toplumsal formasyonda bir direniş pratiği olabilir.

Araçların ve taktiklerin olağanlığı, bu tip eylem biçimlerinin amaçlarını da koşullandırır. Zira bu düzeyde kullanılan araçlar ve taktiklerle yazılan senaryolar, egemen siyasal iktidarı ele geçirmeye ya da değiştirmeye değil, elde bulunan iktidar alanlarını koruyarak, fursatını bulduğu anda iktidar ilişkilerinin çizdiği politik, ekonomik, ideolojik sınırları ihlal etmeye ve yıpratmaya adaydırlar. Dolayısıyla bu sınıfta kullanılan araçların ve taktiklerin nesnel uzam ve zaman düzenlemeleriyle karşı karşıya kalışlarında programlı amaçlardan ziyade, sürecin sonunda elde edilen sonuçlar ön plana çıkar. Diğer bir ifadeyle savunmacı nitelikteki senaryolar, var olan siyasal alanların korunmasını ve yenilerinin ihlaller ve yıpratmalarla kazanımına ilişkin gizil hedefi, eylemin kendisinde billurlaştırırlar. $\mathrm{Bu}$ nedenle, eylemlerin sonucu arızidir. Eylemlerin sonuçlarının arızi olması ise, savunmacı nitelikteki senaryoların aktörlerini Tilly'nin sınıflamasıyla (1978, s.88) "hangi kolektif malı elde edeceklerine bakmaksızın harcanan kaynaklar ve kazanılanlar arasında ikincisinin lehinde bir artış için hareket ederek, bunu azamileştirmeye çalıştıran firsatçılar ile ellerinde tuttukları kaynaklara aşırı değer verdikleri için, başka kaynakların elde edilmesinde harekete geçirilmesi son derece zor olan, kaynaklarını yalnızca çok değerli bir geri dönüş elde edebilecekleri durumda harcayan, herkes birden eylemde bulunduğunda savunmacı bir şekilde eylemde bulunma olasılığ olan sefiller kategorisine sokar. Dolayısıyla savunmacı nitelikteki senaryoların bu düzeydeki aktörleri, aniden beliren bir tahakküm mekanizmasıyla karşılaştıklarında ancak bir ortaklık öğesi yakalayabilirlerse harekete geçirilebilmektedirler. Burada kişiler arasındaki pasif ağlar direnişin koşulunu kurmaktadır. Bu direniş esasında, aktörler perde arkasında gizli senaryolar (Scott, 1995) üretmekte ve firsatını yakaladıkları durumlarda vur-kaç taktikleriyle kendi alanlarını ilerlemeci bir şekilde genişletmeye çalışmaktadırlar. Bu bağlamda savunma niteliğindeki sokak siyaseti repertuvarı bir örgütlenmeden bütünüyle yoksundur. Bir sonraki düzeyle bağlantıya geçmesi de, ancak pasif ağların aktifleşmeye başlamasıyla mümkün olmaktadir. 


\subsection{Saldırı Niteliğinde Senaryolar:}

İçeriklerini teşkil eden araçlar ve taktikler bazında mücadeleyi yine gündelik hayatın akışında yürüten ancak bu sefer bu araç ve taktiklerle egemen siyasal iktidarı ve/veya diğer iktidar ilişkilerini olabildiğince yıpratmayı, sınırları açıkça ihlal etmeyi ve en nihayetinde dönüştürmeyi amaçlayan, bunun paralelinde de tahakkümcü iktidar ilişkilerine karşı konumlanan görünür tecavüzler ve açık senaryolardır. Fanzinler, şehir uzamını "yeniden ele geçirme" talebinden doğan yazılı ve görsel etkinlikler (teknik anlamıyla sokak sanatları), işgal evleri/proje evler, spontane politik toplanmalar bu kategoriden sayılabilir.

Bu nitelikteki senaryolarda çoğunlukla küçük ölçekli, âdem-i merkeziyetçi, antihiyerarşik, fazla tanımlı olmayan gruplar devreye girerler; ancak bu grupların üyeleri, gündelik hayatın akışından kendilerini soyutlamayan, saldırısını programlı bir siyasal davadan değil, gündelik hayatın yerinde ve ânında değiştirilmesi gerekliliğinden türeten kişilerden oluşur. Tilly’nin sınıflandırmasıyla (1978, s.88) "mümkün en az bedel karşılığında bir dizi sınırlı kolektif mal edinmeyi amaçlayan ve değişim gerçekleşirken mobilizasyon ve firsat kombinasyonunun net bir kayba yol açacağının muhtemel görüldüğü durumlarda harekete geçmemeyi tercih eden stradan mücadeleciler" bu grubun aktör kompozisyonunu oluştururlar. Dolayısıyla sınıfsal, kültürel, ideolojik angajmanları itibariyle aktörlerin portföyü son derece değişkendir. Öte yandan aktörler, belli düzeylerde siyasal bilinçle hareket ettiklerinden, yaşam alanları egemen iktidar aygıtları tarafından saldırıya uğradığında, aralarındaki pasif ağlar kolaylıkla aktif ağa dönüşmektedir. Bununla birlikte bu aktif ağlar, kurumsal bir toplumsal harekete nadiren evrilmektedir. Dolayısıyla, bu tarz eylemlerin örgütlenme düzeyinde ibre, pasif ağdan aktif ağa, aktif ağdan pasif ağa doğru sürekli kaymalar göstermektedir.

\subsection{Hazırlık Düzeyindeki Senaryolar:}

İçeriklerini teşkil eden araçlar ve taktikler bazında, önceki senaryoların ülke çapında hacim ve yoğunluk kazanması neticesinde yazılırlar. Çünkü amaç, egemen siyasal iktidarı ele geçirmek veya yıkmaktır. Böylesi bir sokak siyaseti senaryosunun ortaya çıkması, tabandan gelen devrim nosyonuyla çakışır. Burada sokak siyasetinin araçlarıyla dolayımlanan taktiksel manevralar ülke düzeyinde anlam ifade ettikçe, hareketin ibresi aktif ağlardan gelen tazyikle egemen siyasal iktidarı değiştirmeyi hedefleyen topyekûn bir dönüşüme doğru kayar. $\mathrm{Bu}$ doğrultuda, söz konusu nitelikteki senaryoların yazarları, Tilly'nin sınıflandırmasıyla (1978, s.88) "diğer gruplarla karşılaştırıldığında niyetlerini gerçekleştirmek için, örneğin kendi kendini yönetim hakkı kazanmak için, talep edilen kolektif mala, hayatın harcanması dâhil aşırı yüksek değer biçen aşırılardır." Aşırılar, yeni bir zaman ve mekân düzenlemesi projesiyle mevcut mekân ve zaman düzenlemelerine direkt saldırılarla karşı çıkanlardır. Aşırılar kitleselleştiğinde, dolayısıyla "insanların gündelik hayatlarını eskisi gibi 
sürdüremedikleri bu süreçte devrim başlamıştır" (Lefebvre, 2007, s.44). Tabandan gelen devrim nosyonuyla sokak siyasetinin aynılaştığı bu nokta, egemen siyasal iktidar ile karşı iktidarlar arasındaki çatışmanın en yoğun düzeyini işaret etmesi bağlamında, sokak siyasetinin en siyasal ânını temsil etmektedir.

Burada belirtmek gerekir ki, buradaki üç tip senaryo arasında aktörler, örgütlülük, taktikler ve araçlar bakımından geçişlilikler yoğun olarak mevcuttur. Diğer bir ifadeyle ideal birer tip olarak kategorize edilmiş olan bu düzeyler, pratik yaşamın içinde birbirine bulaşmakta, birbirini karakterize ve imal etmektedir. Örneğin sokak sanatları, uzamı kullanan aktörün politik amacıyla ya da amaçsızlığıyla bağıntılı olarak savunma ya da saldırı niteliğindeki senaryolar kategorilerine girebilir. Öte yandan bu düzeyler, sirayla birbirini seyretmezler. Savunmacı düzeyi hazırlık düzeyinin takip etmesi mümkün olabileceği gibi, hazırlık düzeyinden saldırı konumuna geçiş de olasıdır. Örneğin yoğun baskı ve sansür dönemlerinde devrimci hareketin örgütlendiği alanlar, egemen siyasal iktidarın zor aygitları tarafindan tasfiye edilir. Bu durumda, hareketten artakalan elemanlar yer altına iner ve saldırı niteliğindeki eylemlerle kamusal alanı ajite etmenin yollarını ararlar.

Bununla birlikte, ikinci düzeyin, birinci ve üçüncü düzey arasında ilke olarak bir ara katman rolü oynadığını şerh düşmek gerekir. Diğer bir ifadeyle, istisnai durumlar olmasına rağmen üçüncü düzeyde yazılacak senaryolar, ancak savunmacı düzey senaryoların politik bilinç düzeyi daha yüksek saldırı niteliğindeki senaryolarla organik bir ilişki kurması, yani savunmacı senaryoların araçları ve taktikleri sayesinde kurulan pasif ă̆ların, saldırı niteliğindeki senaryoların araçları ve taktikleri ile etkileşime girmesi ve aktifleşmesi ile mümkün olur. Ne var ki pasiften aktif ăga geçiş arasındaki ilişki her zaman olumsaldır. Öte yandan, saldırı ve hazırlık niteliğindeki senaryolar hem pasif hem aktif ăgları içermektedir. Aradaki fark, ilkinin pasif ağları, ikincisininse aktif ağları daha yoğun olarak barındırmasıdır.

Siyasalın gündelik kuruluşu bağlamında sokak siyasetinin bu teorik çerçevesi onu oldukça benzediği Bayatçı anlamdaki sokak siyaseti çerçevesi ile karşılaştırmayı, bu suretle de birbirine yakın iki perspektifin etkileşimini kurarak kent hakk1, toplumsal hareketler, siyasal eylemlilik konularında bütünsel bir bakış açısı sunmay1 gerektirmektedir.

\section{Asef Bayat'וn Sokak Siyaseti: ${ }^{3}$}

Asef Bayat'1n, ilk olarak 1998 yılında ABD'de yayınlanan kitabının adı olan Sokak Siyaseti, üçüncü dünyalı ve özellikle Ortadoğulu madun grupların (köyden, kasabadan kente göç edenler, gecekonducular, işsizler, işportacılar, gündelik/geçimlik işçiler, sığınmacılar) yaşamlarını idame ettirmek ve daha rahat

\footnotetext{
${ }^{3}$ Sokak siyaseti ile ilgili verilen bilgilerin tümü şu eserden derlenmiştir: Bayat, 2009.
} 
yaşam standartlarına ulaşmak için kendi yaşam alanlarında ürettikleri sessiz ve gündelik tecavüz biçimlerini ifade etmek için kullanılan teorik çerçevenin adıdır. Bayat'ın sözleriyle ifade edilirse "sokak siyaseti, halkın bir kısmıyla yetkililer arasında dönemsel olarak -ara sokaklardan daha görünür olan kaldırımlara, umumi parklara ya da spor sahalarına- 'sokakların' fiziksel ve toplumsal mekânında şekillenen ve dile gelen birtakım çatışmalar ve beraberindeki etkilerdir" (Bayat, 2009, s.45). Sokak siyaseti kavram1, "kurumlar, tutarlı bir ideoloji ya da belirgin bir liderlik olmaksızın, farklı toplumsal grupların muhalefetinin ilerleyişini ifade eder." (Bayat, 2009, s.35). Söz konusu ilerleyiş Bayat'ın terminolojisinde stradanın sessiz tecavüzü olarak ifade edilir. Buna göre sessiz tecavüz,

“...sıradan insanın zorlukları aşmak ve daha iyi bir yaşam sürdürebilmek için mülk sahipleri ve güçlülerin üzerine sessiz, sabırlı, uzun soluklu ve israrlı yürüyüşüdür. Aktörlerine önemli kazanımlar sağlayarak zaman içinde devlete karşı bir konuma yerleştiren, belirgin liderliği, ideolojisi ya da örgüt yapısı olmayan, açık ve uçucu mücadeleler şeklinde dönemsel kolektif eylemleri de içeren, sessiz, münferit ve uzun soluklu hareketlerdir. İlle de siyasal otoriteyi zayıflatmayı hedeflemezler. Sessiz tecavüzün kilit özelliklerinden biri ilerlemeler sessizce, münferit ve kademeli gerçekleştirilirken kazanımların savunusunun her zaman kolektif ve ses getirici olmasıdır." (Bayat, 2009, s.36).

$\mathrm{Bu}$ bağlamda sessiz tecavüzlerle kazanılmış bir alan, egemen siyasal iktidar tarafından tehdit edildiğinde, sokak siyasetinin aktörleri bu kazanımları savunmaya ve mümkünse daha da artırmaya yönelirler. Sessiz tecavüzün siyasallaştı̆̆ 1 yer, tam da burasıdır. Söz konusu siyasallaşma ise, sessiz tecavüzün aktörleri arasında kendiliğinden kurulmuş olan pasif ağlar yoluyla gerçekleşir. Pasif ă̆, içinde olanlar birbirlerini tanımasalar da ortak bir mekânı paylaşıyor olmalarından dolayı ani bir tehditle karşılaşıldığında birlikte hareket edebilecek kişilerin kurduğu bir birliktelik şeklidir. Örneğin maç sonrası polisle çatışan futbol taraftarları ya da zabıta ekipleri tarafından kovalanan işportacıları bir araya getiren, bu kişiler arasında oluşmuş pasif ağlardır. Karşılaştırılarak bakıldığında bu pasif ağlar, siyasalın gündelik kuruluşu bağlamında sokak siyasetinin de temel hareket düzeyidir. Zira sessiz tecavüz neticesinde gerçekleşen kazanımların savunusu ve artırımında, diğer bir ifadeyle nesnel zaman ve uzam düzenlemelerine karşı gerçekleştirilen öznel zaman ve uzam düzenlemelerinin egemen iktidar ilişkileriyle karşı karşıya geldiği ani kriz anlarında direniş, ancak bu pasif ağların harekete geçmesi sayesinde mümkün olabilmektedir. Burada, mücadelelerin tutarlı ve süreğen bir yapıda olması gerekmez; ancak bunların makro düzeyde siyasete etki edecek toplumsal hareket biçimlerine dönüşme ihtimali de vardır. Yeni toplumsal hareketlerin fitilini ateşleyen üniversite işgalleri böylesi bir dönüşüme iyi bir örnektir. Dolayısıyla sokak, içinde barındırdığı pasif ăgların geçici ya da kalıcı aktif ağlara dönüşmesi ihtimalini içinde barındırdığından potansiyel bir çatışma alanı haline gelir. Egemen iktidarın, 
sokağı denetlemeye yönelik istekliliğinin nedenlerinden biri de bu potansiyelin önünün kesilmesidir.

Görüldügü üzere Bayat'ın çözümlemesi siyasal bilinç düzeyi yüksek, örgütlü mücadelelerin haricinde sıradan insanın gündelik eylemler ve sessiz ilerlemelerle siyaseti şekillendirme biçim ve potansiyellerini ele almaktadır. $\mathrm{Bu}$ anlamda burada ifade edilen biçimiyle siyasalın gündelik kuruluşu bağlamında sokak siyaseti, Bayat'ınkiyle doğrudan göbek bağına sahiptir. Zira siyasalın gündelik kuruluşu bağlamında sokak siyaseti, öznel zaman ve uzam düzenlemelerinin siyasal alanı kurmadaki ve dönüştürmedeki rolünü incelediği ölçüde, gündelik yaşamda gerçekleşen sessiz tecavüzleri siyasal alan mücadelesine eklemlemektedir. Ne var ki, Bayatçı sokak siyasetini kimi noktalarda eleştirerek, ondan bazı noktalarda ayrılmaktadır.

Eleştiri noktalarından ilki, Bayat'ın sokak siyasetini yalnızca üçüncü dünyalı ve özelde de Ortadoğulu halklar nezdinde düşünmüş olmasına yöneliktir. Diğer bir ifadeyle Bayat, sıradanın sessiz tecavüzünün gerçekleştiği alanları üçüncü dünya ile sınırlamakta ve Batı'da sıradanın sessiz tecavüzü konusuna ilgisiz kalmaktadır. Oysa farklı ekonomik, politik ve ideolojik bağlamlarda gerçekleşse de sıradanın sessiz tecavüzünün Batılı karşılıklarının da olduğu saptanabilir. Kuşkusuz, Bayat'ın da belirttiği gibi, devletin demokratiklik oranı ile gayri resmi ve kayıt dışı yollardan yaşamı idame ettirme isteği arasında ters orantı olması, Batılı toplumlar nezdinde sıradanın sessiz tecavüzlerinin niceliğini azaltmaktadır; ancak bu durum, tecavüzlerin olmadığını göstermemektedir. Bu bağlamda, demokratik Batı toplumlarında sıradanın sessiz tecavüzünün ne anlama geldiği bu coğrafi konjonktür bağlamında yeniden düşünülebilir. Örneğin Berlin'in özellikle doğusunda yer alan metro istasyonlarında işportacılara, kaçak sigara satıcılarına siklıkla rastlanmaktadır.

Öte yandan Bayat, sokak siyasetini toplumsal malların yeniden bölüşümü (arazi, barınak, şebeke suyu, elektrik, yol gibi hizmetlerin kaçak kullanımlar yoluyla elde edilmesi) nazarında değerlendirdiği için, sessiz tecavüzleri de devletin koyduğu kuralların ihlal edilmesi olarak sinırlamakta, dolayısıyla eylem repertuvarını sadece 20. ve 21. asırlara odaklanarak incelemektedir. Gerçi Bayat, bu tarz etkinliklerin yeni olmadığını 16. ve 18. yüzyıl Avrupa'sında da görüldüğünü söylemektedir; ancak bunların sokak siyasetini beraberinde getirmediğini vurgulamaktadır. Böylelikle Bayat, sokak siyaseti ile siyasal sokak etkinliğini birbirinden ayırmaktadır. İlkinin ölçütlerini belirlemektedir; ancak ikincisinin birincisinden ne yönlerden ayrıldığını göstermediği için siyasal sokak etkinliğinin nasıl bir çerçeveye oturacağı açıklanmamaktadır. Bu noktada, sıradanın sessiz tecavüzünü devlete karşı konumlandırmak yerine, iktidar ilişkilerinin tahakkümcü yapılarına karşı düşünmek, bunu tarihteki diğer görünümleriyle çoğullaştırmanın yolunu açabilir. Örneğin plantasyonlarda kölelerin bir ağızdan tutturduğu ritmik şarkılar, sömürge düzeninin onlar üzerinde uyguladığı maddi ve sembolik şiddete 
karş1 anlamsal bir tecavüzdür. (Scott, 1995, s.31). Gerçi Scott'ın gündelik direniş biçimleri olarak sınıflandırdığı bu tarz pratikleri Bayat, bunların sokak siyaseti bağlamında değerlendirilecek şekilde birer saldırı değil, savunma mekanizması olduğunu söylemektedir. Ne var ki, egemen iktidar ilişkilerine karşı bir özerklik alanı yaratan her direniş biçimi, mevcut düzenin dayattığı bir kurala yönelik zamansal ya da mekânsal bir deformasyonu içerdiğinden bir saldırı olarak da görülebilir. Gündelik yaşam içinde vücuda gelen direniş biçimleri, Bayat'in ifade ettiği gibi "yaşamak ve onurlu yaşamak zoruyla sürüklenerek" yapılan sessiz tecavüzlere eklemlidirler. Dolayısıyla mücadele pratiklerini, savunmaci ile saldırgan ikiliği üzerinden okumak yerine bunları gündelik yaşamda üst üste binen, egemen iktidar ilişkilerinin maddi ve sembolik görünümlerini yıpratan, bu suretle vücuda gelen pratik bir mesele olarak görmek daha elverişlidir.

Bayatçı anlamda sokak siyaseti ile siyasetin gündelik kuruluşu bağlamında sokak siyaseti arasındaki en büyük kırılma ise ilkinin gövdesinde yer alan "siyasal bilinç yoksunluğu" noktasında dügümlenmektedir. Bayat'a göre, sokak siyaseti "aktörler amaçlarını, yöntemlerini ve gerekçelerini telaffuz ederek eylemlerinin bilincine varırlarsa toplumsal hareket haline gelen kendinde bir harekettir" (Bayat, 2009, s.35). Diğer bir ifadeyle, sessiz tecavüz aşamasında ve eylemler siyasallaşmadan önce -tehdidi meydana getiren iktidar yapılarıyla karşılaşılmadan önce- aktörler eylemlerinin siyasal niteliğine ilişkin herhangi bir bilinçten yoksundurlar. Burada bilinç kendiliğinden bir hareketi toplumsal harekete dönüştüren bir ölçüt olarak devreye girmektedir. Ne var ki, söz konusu ölçüt, siyasalın gündelik kuruluşu bağlamında sokak siyaseti çerçevesinden bakıldığında sokak siyasetinin alanını son derece kısıtlamaktadır. Zira sessiz tecavüzü sadece siyasi bilinç taşımayan kişilere özgülemektedir. Siyasal bilinçle yapılmış sessiz tecavüzleri kolaylıkla toplumsal hareket kataloğu içine koymaktadır. Oysa bir kolektif eylemin toplumsal hareket niteliği kazanabilmesi için başka ölçütler -program ve kimlik, Özne betisi geliştirme gibi- de (Tilly, 2008; Touraine,2011) gerekmektedir. Öte yandan, insanların ne ölçüde siyasal bir bilinçle sessiz tecavüze giriştiğini, ne büyüklükte genel siyasal iklimi değiştirmeye dönük veya buna muktedir eylemlerde bulunduğunu ölçmek zordur. Zira direniş ile sessiz tecavüzün, reaksiyoner eylemlilikten örgütlü hak talebine dönüşmesine kısa bir mesafe vardır. Burada siyasal bilinç açısından önemli olan, gizli senaryoların/tabi grupların altpolitikasının, pratik direnişin bir ikamesi değil, bir koşulu olmasıdır (Scott, 1995, s.259). Nitekim pratik direnişin getirdiği kazanımlar hâkim grupların siyaseti ile bütünleşmeyi garanti etmediği gibi (Es, 1976, s.16), gizli senaryoların üretimini de durdurmamaktadır. Dolayısıyla siyasal alanda dönüşüm yaratmaya aday sokak siyaseti etkinliklerini tespit etmede siyasal bilinç edinmiş olanları toplumsal hareket, edinmemiş tecavüzleri ise sokak siyaseti kataloğuna koymak bu eleştiriler dikkate alındığında elverişli değildir.

Öte yandan kurumsal politik mekanizmalar dışında sokağın dinamiklerinden türeyen siyasal mücadeleleri, gizli olarak yazılmaları veya tam anlamıyla sessiz 
bir tecavüz olmaları esasında sınıflandırmak da sokak eylemlerinin çeşitliliğini sınırlamaktadır. Zira gündelik yaşam pratiklerinden türemesi bakımından bir direniş niteliği gösteren ancak açık açık ifade edilen senaryolar da mevcuttur. Açık senaryolar, saldırılan alanda kalıcı, uzun soluklu ilerleyişler sağlayamayan; ancak toplumsal bir tepki neticesinde spontane olarak kitleselleşerek maddi ya da sembolik bir alanı tutmaya yarayan direniş biçimleridir. Buna örnek olarak, Türkiye'de Susurluk olayı ile ortaya çıkan karanlık ilişkileri protesto etmek için yapılan sürekli aydınlık için bir dakika karanlık eylemi gösterilebilir. Bu eylem, bir siyasi programdan yoksun olmasıyla merkezsiz, aktörlerinin belirli bir kimliğe ait olmamasıyla sıradan, insanlar arasındaki pasif ă̆lar vasıtasıyla hayata geçtiği için sokağa dair, spontane olarak kitleselleşmekle birlikte göstere göstere yapıldığı için açık bir senaryodur. Diğer taraftan, stradanın sessiz tecavüzünden, aktörlerinin tecavüzlerini sesli bir şekilde gerçekleştirmesiyle ayrılan sıradanın sesli tecavüzleri de mevcuttur. Buna örnek olarak da Bat1 Avrupa'daki ev işgalleri gösterilebilir. Zira bu işgallerde aktörler, Bayat'ın üçüncü dünyalı sessiz tecavüzcülerine zit şekilde devletten özerk bir alanda hareket etmemelerine rağmen yine de ilerlemeci bir şekilde saldırgandırlar.

$\mathrm{Bu}$ kesişme ve ayrılık noktaları, Bayatçı anlamdaki sokak siyasetini siyasalın gündelik kuruluşu bağlamında sokak siyasetinin alt kümesi yapmaktadır. Zira ilki, ikincisine göre daha sıkı tanımlanmış kavramsal setler kullanmaktadır. Siyasalın gündelik kuruluşu anlamında sokak siyaseti çerçevesi, Bayat'ın bakışından farklı olarak siyasal bilinçle hareket eden aktör gruplarını küme içine aldığı gibi, sıradanın sessiz tecavüzleri yanında sesli tecavüzlerini, gizli senaryolar yanında açık senaryoları tanımakta ve coğrafi bakış açısını sadece Orta Doğu ile sınırlamamakta, tarihsel bakış açısını ise genişletmektedir.

\section{Sonuç}

Siyasalın gündelik kuruluşu bağlamında sokak siyaseti teorik düzlemde siyasal tanımına binaen yükselir. Burada siyasal, parti, parlamento, hükümet gibi modern siyasal iktidar aygıtlarının insanları idare etme, sınıflama, düzenleme ve disipline etme etkinliklerinin uzmanlaşmış alanını gösteren modern anlamlı siyaset olgusundan farklı olarak, insanların hak ve çıar mücadelelerinin içinden şekillenen dolayısıyla farklı iktidar kombinasyonlarını içine alan çok boyutlu bir matristir. Bu çerçevede de zamanın ve uzamın sınırlarının çizilmesi, değiştirilmesi ve muğlaklaştırılması olarak hem makro yapılar hem de bu yapılar içinde eyleyen mikro aktörler arasında gelișen bir alan mücadelesinin tezahürüdür. Buna istinaden siyasal, taraflarca her gün yeniden inşa edilen agonistik bir karakteri haizdir.

Öte yandan siyasal bir kez alan agonistik bir alan mücadelesi olarak tanımlandığında, alan kavramının içinde bulunan zaman ve uzam yüklemlerini devreye sokmak gerekir. Bu minvalde ölçüm araçlarıyla sabitleştirilmiş nesnel zamana karşılık kişilerin bu sabitleştirilmiş zamana dönük öznel 
manipülasyonlarını içeren öznel zaman; yine ölçüm ve planlamalarla anlamı ve içeriği belirlenmiş nesnel uzama karşılık kişilerin bu belirlenmiş uzama dönük öznel manipülasyonlarını içeren öznel uzam mücadele pratiklerinin ana aksını oluşturmaktadır. Nihayetinde sosyolojik kategoriler olarak yapılara karşı failler, sisteme karşı eylem her zaman kendi öznel-nesnel zaman ve uzam düzenlemeleri itibariyle bitimsiz bir mücadelenin tarafları olmaktadırlar.

Siyasalın gündelik kuruluşu bağlamında sokak siyaseti de siyasal olana ilişkin bu anlayıştan beslendiği ölçüde sıradan insanların gündelik yaşam pratikleri içinde egemen iktidarların alanından nasıl ve hangi suretlerle alan devşirdiğini anlamaya dönük bir analitik çerçeve olarak belirmektedir.

Bu çerçevede siyasalın gündelik kuruluşu bağlamında sokak siyasetinin aktörleri, sıradan insanlardır. Belli bir siyasal hedef güdülsün ya da güdülmesin herkes her an sokak siyasetinin aktörleri arasında yer alabilir. Bunun nedeni, sokak siyasetinin araçları olarak sınıflandırdığımız karnavallaşma, mizah, müzik/dans, fantasma (hayal), esriklik, aylaklık, oyun, armağan, sokak sanatları, internet, spontane toplanmalar ve işgallerin zaten gündelik yaşam içine gömülü oluşlarıdır. Her bir araç vasıtasıyla insanlar, şu ya da bu şekilde gündelik yaşamın akışına, dolayısıyla siyasal alana müdahalede bulunabilirler/bulunurlar.

Sokak siyaseti araçlarının gündelik hayatın içine bu denli gömülü olması, eylemlerin karakterini spontane, hiyerarşisiz ve âdem-i merkeziyetçi kılar. Ne var ki bu araçların ne şekilde ve ne amaçla kullanıldığına da bağlı olarak sokak siyaseti repertuvarı anlık hak mücadelelerinden tabandan gelen devrime farklı düzeylerde politik anlamlar ortaya çıkarır. Bu düzeyler, savunmacı nitelikte, saldırı niteliğinde ve hazırlık niteliğinde senaryolar olarak üçe ayrılır. İlkinden sonuncusuna makro iktidar yapılarından devşirilmeye çalışılan alan talebi şiddetlenir. Her bir düzeyde aktörler, çıkarlarını maksimize etmek için pasif ya da aktif ağlar vasıtasıyla örgütlenir ve gizli ya da açık senaryolar yazar, stratejilere karşı taktikler kullanırlar.

Tüm bu çerçeve itibariyle siyasalın gündelik kuruluşu bağlamında sokak siyaseti çerçevesi, Bayatçı anlamdaki sokak siyaseti ile oldukça büyük benzerlikler taşısa da siyasal bilince sahip olan hareketleri, sıradanın açık senaryolarını ve görünür tecavüzlerini dikkate almanın yanında bakış açısını Orta Doğu'yla sınırlandırmadığı için ondan ayrılır. 


\section{Kaynakça}

Bayat, A. (2009). Sokak siyaseti: Iran'da yoksul halk hareketleri, (S. Torlak, Çev.). Ankara: Phoenix Yayınevi).

Bourdieu, P. (1989). Social space and sembolic power. Sociological Theory, 7(1), $14-25$.

De Certeau, M., (1990). Gündelik hayatın keşfi I: Eylem, uygulama, üretim sanatları. (L.A. Özcan, Çev.). Ankara:Dost Yayınevi.

Çoban, F. (2015). Sokak siyaseti: siyasalın gündelik kuruluşu bağlamında bir inceleme. İstanbul: Metis Yayınevi.

Es, J.C.V. (1976). Social participation, social status and extremist political attitudes. Sociological Quarterly, 17(1), 16-26.

Gill, M. (2009). Eccentricity and the cultural imagination in nineteenth-century Paris. Oxford: Oxford University Press.

Ginzburg, C. (2007). Efsaneler-amblemler-izler: Morfoloji ve tarih, (M. Moral1, Çev). İstanbul: Kırmızı Yayınları.

Griffiths, P. (1998). Meanings of nightwalking in early modern England. Seventeenth Century, 13(2), 212-238.

Healy, P., (2006). Pollachos polis legetai (there are many ways to say polis) or : community and the visible of the city. Stephen Read ve Camilo Pinilla (Ed.), Visualizing the invisible: towards an urban space içinde (s.20-31). Amsterdam: Techno Press.

Lefebvre, H. (2007). Modern dünyada gündelik hayat. (I. Gürbüz, Çev.). İstanbul: Metis Yayınları

Mouffe C. (2010). Siyasal üzerine, (M. Ratip, Çev.). İstanbul: İletişim Yayınları.

Neocleous, M. (2006). Toplumsal düzenin inşası, (A. Bekmen, Çev.). İstanbul: Boğaziçi Üniversitesi Yayınevi.

Rawlings, P. (2002). Drunks, whores and idle apprentices: criminal biographies of the 18th century. New York: Routledge.

Reynolds,B. (2002). Becoming criminal: transversal performance and cultural dissidence in early modern England. London: Johns Hopkins University Press. 
Scott, J.C. (2005). Tahakküm ve direniş sanatlart: gizli senaryolar. (A. Türker). İstanbul: Ayrıntı Yayınları.

Tilly, C. (2008). Toplumsal hareketler (1768-2004). (O.Düz, Çev.). İstanbul: Babil Yayınları.

Touraine, A. (2011). Birlikte yaşayabilecek miyiz?. (O. Kunal, Çev.). İstanbul: YKY.

Vollrath, E. (1973), Rosa Luxemburg's theory of revolution. Social Research, 40(1), 83-109.

Wooley, H. (2003). Urban open spaces. New York: Spon Press. 


\title{
Street Politics in the Context of Everday Construction of Political
}

\author{
Extended Abstract
}

\section{Introduction}

The study at hand focuses on the theoretical framework named street politics in the context of the everyday construction of political. According to that, the article firstly makes a general distinction between the concepts, politics, and political. Following this, it depicts political as a struggle for a field. By addressing the field including the two-dimensional concepts of time, and space it makes another distinction between objective time-space settings and the subjective time-space compositions which all correspond to the confrontation between the macro-level structures and micro-level agents. Thus, the study explains street politics (in the context of everyday construction of political) in terms of actors, organizational form, action areas, and action repertoires. In the end, it compares street politics in the context of everyday construction of political with street politics by Bayat. Thus, it clarifies the conceptual and theoretical framework in a comparative way.

\section{Method}

The study at hand uses a hermeneutic perspective to build the theoretical framework about political as a struggle for the field while it benefits from the relevant literature to deepen this main discussion in a comparative way. Also, the ethnomethodological perspective provides a framework to interpret the flow of everydayness in terms of street politics in the context of everyday construction of political.

\section{Results and Discussion}

Street politics in the context of the everyday construction of the political rises on the theoretical level based on the definition of political. Here, the term, political refers to a multidimensional matrix, which is shaped through people's struggles for rights and interests, and therefore includes different combinations of power, unlike the term, politics in its modern sense, which outlines the specialized field of the activities of modern political power apparatus such as party, parliament, and, government which of each operates to classify, regulate and discipline people. In this context, political is the manifestation of a field struggle ongoing between both macro structures and micro actors to determine, change and blur the boundaries of time and space. Based on this, the political has an agonistic character that is rebuilt every day by the parties.

On the other hand, once the political field is defined as an agonistic field struggle, it is also necessary to review the ontological character of time and space included in the field. In this sense, time can be categorized as subjective time and objective time. Here, subjective time refers to the subjective manipulations of individuals towards fixed time determined by measuring instruments, such as clocks or calendars, whereas objective time refers to those meanings and contents determined by measurement and planning of the public time. From a similar perspective, an objective space refers to the place which is designed and built by official authorities for common public usage while a subjective space refers to the place whose usage is interpreted, reshaped, and manipulated by micro-level actors. In terms of sociological categories, this classification matches the rivalry between agents and structures or action and system. Thus, the agonistic character of political emerges as an endless struggle in terms of subjective-objective time and space arrangements. 
In this sense, as the product of deduction about the assumed field struggle, street politics in the context of the everyday construction of politics is an analytical framework to understand how and in what ways ordinary people gain the domain of the dominant powers by their daily life practices. Following this framework, the actors of street politics are ordinary people. Whether or not a specific political goal is motivated, anyone can be among the actors of street politics at any time. This is because carnivalization, humor, music/dance, fantasma (fantasy), ecstasy, idleness, games, gifts, street arts, internet, spontaneous gatherings, and occupations, which we classify as the tools of street politics, are already embedded in everyday life. Utilizing each tool, people can intervene in the flow of daily life in one way or another, and therefore in the political field.

The fact that the means of street politics are so embedded in everyday life makes the character of the actions spontaneous, non-hierarchical, and decentralized. However, depending on how and for what purpose these tools are used, the street politics repertoire reveals political meanings at different levels, from struggles for rights to grassroots revolution. These levels are divided into three scenarios: defensive, offensive, and preparatory. From the first to the last, the demand for the field that is tried to be recruited from macro power structures intensifies. At each level, actors organize through passive or active networks to maximize their interests, and emerge secret or explicit scenarios and use tactics against strategies.

All the features of street politics in the context of everyday construction of political arises a question how close it is to the theoretical framework of street politics asserted by Asef Bayat. Discussion with Bayat's project named street politics, however, clarifies this framework differs from his at some points regarding political consciousness, grassroots scenarios, and geographical map of street politics.

\section{Conclusion}

Street politics in the context of the everyday construction of political differs from the theoretical framework of street politics of Bayat because it does not geographically limit its point of view to the Middle East, in addition to taking into account the movements with political consciousness, open-scenarios, and visible encroachments, even though the framework of street politics bears quite similarities with the street politics in the context of everyday construction of politics. However, these sets of frameworks need to be supported by emprical studies. Future projection analyzing the models within field research would contribute to the strength of theory. 